Plant Tissue Cult. \& Biotech. 26(1): 1-14, 2016 (June)

$\overline{\text { PTC\&B }}$

\title{
A Simple Reliable Protocol for Cytogentically Stable Mass Propagation of Ornithogalum virens Lindl.
}

\author{
Saswati Bhattacharya1, Biswajit Ghosh² and Madhubrata \\ Choudhury*
}

Department of Biological Sciences, Presidency University, Kolkata 700073, West Bengal, India

Key words: Ornithogalum virens, Micropropagation, Chromosome, RAPD

\begin{abstract}
Ornithogalum virens is a plant of horticultural importance but recently researches are focused on its medicinal importance. A simple reliable protocol has been standardized for micropropagation of $O$. virens to produce a cytologically stable progeny with least polysomatic variation of chromosome number. Among different explants, bulb scales showed the maximum potential for organogenesis. From a single bulb scale 37 bulblets have been produced within 16 weeks of inoculation. A low concentration of auxin with different concentrations of cytokinin is suitable for organogenesis. A higher level of auxin induces callus formation. Bulblet production was the maximum in the medium supplemented with $0.5 \mathrm{mg} / \mathrm{l} \mathrm{NAA}$ and $2 \mathrm{mg} / \mathrm{l} 2 \mathrm{iP}$. O. virens normally has a chromosome number of $2 n=6$. In nature it shows a common occurrence of polysomaty. The somatic plates that deviate from normal $2 \mathrm{n}=6$ specially $2 \mathrm{n}=12$ are of quite common occurrence (approximately 18 - 25\% per root tip). Strikingly the tissue culture regenerants show a uniform chromosome number $2 n=6$, frequency of polyploidy being negligible. RAPD profile of the explants and its regenerants are almost same. Five primer sets give more number of bands with explants' DNA. Moreover, the intensity of the bands of source plant is sometimes more than that of the regenerants. This may coincides with the fact that in the source plant the somatic chromosome number is $2 n=6$ and 12 , whereas in regenerants it is $2 n=6$.
\end{abstract}

\section{Introduction}

The generic name Ornithogalum is derived from the Greek word "Ornithos" meaning bird and "gala" means milk. "Birds milk" was frequently used by

*Author for correspondence: <mbchoudhury11@gmail.com>. ${ }^{1}$ Department of Botany, Dr A.P.J Abdul Kalam Govt. College, New Town, Kolkata, West Bengal, India. ${ }^{2}$ Department of Botany, Ramakrishna Mission Vivekananda Centenary College, Rahara, West Bengal, India. 
Romans to indicate something wonderful (Smith 1966). The genus Ornithogalum L. belongs Asparagaceae in the class Liliopsida. It contains 180 species found in the temperate regions of Africa, Asia and Europe (Obermeyer 1978). The plant bears the following common names: Star of Bethlehem, Sleepy-dick, Wonder flower, South African star flower, Chincherinchee etc.

The plant for its beautiful white flowers is used as an ornamental garden plant. In Kenya, it is being exported every year (Muthoka 2008). In India Ornithogalum is priced for its beautiful flowers. The price ranges from Rs 5 to Rs 50 (INR) per bulb.

This plant is of immense medicinal importance but this aspect has been less focused in earlier research work. However, previous studies on some other Ornithogalum species revealed the presence of steroidal glycosides (Komissarenko 1971), monoterpenelactone (Tang et al. 2002) and homoisoflavone (Kuroda et al. 2002) some of which were found to possess antimicrobial, cytotoxic, cytostatic, anticancer, antioxidant, mould inhibiting and insect deterrent properties (Ebrahimzadeh 2010). The naturally occurring compound $3 \beta, 16 \beta, 17 \alpha$-trihydroxycholest-5-en 22-one 16-O (2-O-4 methoxybenzoyl- $\beta$-Dxylopyranosyl)-(2-O-acetyl- $\alpha$-L-arabinopyranoside) (OSW-1) is found in the bulbs of $O$. saudersiae and is highly cytotoxic against tumor cell lines. It shows high cytotoxic activity against cancer cells in vitro (Zohu et al. 2005). But those species are commonly not available in our localities in India. Intensive work on this aspect is yet to be done in Ornithogalum species available in adjoining localities.

O. umbellatum is highly valued in homeopathy medicines. The diluted extracts are useful in the treatment of stomach upsets such as gastric ulcers, peptic ulcers, duodenal ulcers acidity etc. Thus on the basis of recent phytochemical research, Ornithogalum is highly valued as an important medicinal plant.

The species of Ornithogalum are temperate; hence it is quite difficult to work with it in tropical regions. Moreover, the rate of propagation of the plant is as slow as $4-6$ plantlets annually (Nayak 2005). Therefore, to work with a large population of $O$. virens, tissue culture is perhaps the only way.

The genus Ornithogalum is normally propagated vegetatively through bulbs. Propagation through seeds is almost impractical as it takes too long to germinate and ultimately to flower (Karaguzel et al. 2012). Moreover the propagules, namely the bulbs often get infected by a soil borne bacterium Erwinia carotovora causing in some years 100\% crop loss (Mbaka 2003). Hence, the convenient way to propagate the plant, especially in warmer climates is through tissue culture. In this study, authors have focused on formulating a protocol for direct 
organogenesis of O. virens. Moreover, cytological studies of this plant species show a great variation in somatic chromosome number, $2 n=6$ being normal but in in vivo system $2 \mathrm{n}=12$ is of frequent occurrence. Strikingly, the tissue culture grown plants maintain a uniformity of chromosome number where the somatic chromosome number is $2 \mathrm{n}=6$ being almost constant.

\section{Materials and Methods}

O. virens is a bulbous perennial plant exotic to India but grows wild in temperate north and north east. The leaves are linear and basal with long inflorescence stalks. The bulbs were collected from Surajmukhi Nursery stores, Darjeeling and were duly identified. A few of the bulbs were planted in the greenhouse, some were used for tissue culture and rest were wrapped in blotting paper and stored.

For the purpose of in vitro culture of $O$. virens, five different types of explants, namely bulb scales, leaf apices, leaf bases and inflorescence stalks, and small whole bulbs were used. Among all these, scales of small to medium sized bulbs $(\mathrm{L} \times \mathrm{B}: 1-3.8 \times 0.7-2.8 \mathrm{~cm})$ gave the best results. The larger bulbs $(\mathrm{L} \times \mathrm{B}: 3-$ $5 \times 3-5$ ) remain quiescent for a longer time (17 - 21 days) after inoculation in the media while the smaller ones respond within 7 days. After removal of the outer dry scales, bulbs were washed rigorously in tap water followed by rinsing them several times with distilled water. Thereafter, the bulbs were soaked in $1 \%$ Bavistin solution for about $45 \mathrm{~min}$. The bulbs were again washed thoroughly with distilled water and soaked in a solution of $0.05 \%$ mercuric chloride. After 30 $\mathrm{min}$, the bulbs were washed in sterile double distilled water for 5 times. Some of the bulbs were cut to pieces to have the scale leaves and some smaller $(\mathrm{L} \times \mathrm{B} 0.5 \times$ $0.5 \mathrm{~cm}$ ) ones were kept intact and all were transferred to MS.

MS was prepared using synthetic media powder (Hi-Media Cat No PT 021). The medium was supplemented with 3\% (w/v) sucrose (Merck) and $0.81 \%$ agar (Qualigen, USA, Bacteriological grade). In accordance with the requirement, different combinations of plant growth regulators (Sigma Aldrich, USA) like 1NAA, IAA, BAP, 2iP, Kn, 2, 4-D were used. The $\mathrm{pH}$ was adjusted to $5.74( \pm 0.02)$. The media was autoclaved at $121^{\circ} \mathrm{C}$ temperature and $17 \mathrm{lb}$ pressure for $20 \mathrm{~min}$.

The cultures were maintained at a temperature of $22^{\circ} \mathrm{C}( \pm 2)$ and at $16: 8$ (Light : dark) photoperiod (Light intensity: $100 \mu \mathrm{mol} / \mathrm{m}^{2} / \mathrm{s}$ ). The sub-culturing was done every three weeks. For each set of plant growth regulator combinations, 3 sets of replica were prepared.

Eighteen week old regenerated plants, with young bulbs each approximately $\mathrm{L} \times \mathrm{B} 0.5-2.5 \times 0.7-3 \mathrm{~cm}$ in size were transferred to MS basal medium supplemented with $0.8 \%$ agar and maintained for two weeks and then 
transferred to pots containing a sterile mixture of soil and soilrites (Keltech Energies Ltd., India) in $1: 1$. After a month, plants were shifted to the greenhouse and after another month they were kept in natural weather conditions.

Root tips were collected from the source plants and as well as tissue culture raised regenerants. The roots were pretreated with a mixture of $(0.5 \%)$ colchicine (Sigma- Aldrich, USA): super saturated para-di chlorobenzene (Sigma- Aldrich, USA) $(1: 2)$ for $5 \mathrm{hrs}$ at $12^{\circ} \mathrm{C}$. Roots were then fixed in $1: 3$ acetic acid:ethanol and duly stained and squashed following aceto-orcein technique (Sharma and Sharma 1980). Karyogram and idiograms were prepared using ProGres, Jenoptik software.

Extraction and purification of the DNA from leaf tissue of the source plant as well as tissue culture regenerants were done using Qiagen DNeasy mini kit (Cat. No. 69104). Concentration and purity of the extracted DNA were checked in a Nanodrop (Eppendorf, Germany). For carrying out PCR a total volume of $25 \mu \mathrm{l}$ of reaction mixture for each set of template and primer was prepared. Each reaction set contained $5 \mu \mathrm{l}$ of Green Go Taq Flexi buffer (Promega), $3 \mu \mathrm{l}$ of $\mathrm{MgCl}_{2}$ (Promega), $0.25 \mu \mathrm{l}$ of Taq polymerase (Promega, USA), $0.5 \mu \mathrm{l}$ of nucleotide mix (Biolines, London) of $100 \mu \mathrm{M}$ concentration, $2 \mu \mathrm{l}$ of decamer primers (IDT) (Details of primer sequence and their respective Tm are mentioned in Table: 4 ) of $10 \mu \mathrm{M}$ concentration and $25 \mathrm{ng}$ of template DNA. After PCR, the products were subjected to gel electrophoresis, in a $1.8 \%$ agarose (SRL, low EEO) slab using $1 \mathrm{X}$ TAE buffer along with a standard of 100 bp (NEB: N3231S). The visualization and documentation of the gel were done using gel doc of Kodak Molecular imaging software.

\section{Results and Discussion}

The plant parts those were used as explants on media consisted of leaf tips, leaf bases, inflorescence stalks, bulb scales and small whole bulbs. Of these, bulb scales and whole bulbs showed the maximum potential for direct organogenesis while other explants get browned and withered within two weeks from the date of inoculation. Fifty per cent of the bulbs sprouted within seven days of inoculation and within 24 days $90 \%$ of the bulb scales and $100 \%$ of the whole bulbs sprouted. The cultures were maintained in different sets with one set in MS basal while others were supplemented with either $0.5 \mathrm{mg} / 1 \mathrm{NAA}$ or $0.5 \mathrm{mg} / \mathrm{l} \mathrm{IAA}$ each in combination with varying concentrations of BAP. For each set 5 replicates were made. In MS basal medium sprouting started within 7 days and $90 \%$ of the explants showed shoot initiation. In the sets those supplemented with plant growth regulators, initiation was a little delayed. Within 12 days $60 \%$ of the explants started sprouting. Among total successful shoot initiation, $70 \%$ of the 
shooting started as adventitious shoot either from the inner side of the bulb scale or in between two scale leaves and in rest $30 \%$ greening of the adaxial portion of the scale leaves were noticed which after another week led to shoot initiation. Strikingly time span for shoot initiation was little shorter in case of the scale leaves rather than whole bulbs. For scale leaves, it was seven days but for whole bulbs, shooting started on the 10th day. Shoot initiation was best in the media supplemented with $0.5 \mathrm{mg} / \mathrm{l} \mathrm{NAA}$ and $2 \mathrm{mg} / \mathrm{l} \mathrm{BAP}$ while shoot proliferation was best in PGR combinations $0.5 \mathrm{mg} / \mathrm{l} \mathrm{NAA}$ and $1 \mathrm{mg} / \mathrm{l} \mathrm{BAP}$ (Table 1).

Table 1. Effect of different combinations of plant growth regulators (PGR) on shoot induction and shoot proliferation.

\begin{tabular}{llll}
\hline $\begin{array}{l}\text { Sl. } \\
\text { No. }\end{array}$ & $\begin{array}{l}\text { PGR } \\
\text { composition }\end{array}$ & $\begin{array}{l}\text { Shoot induction } \\
(\text { after } 2 \text { weeks })\end{array}$ & $\begin{array}{l}\text { Shoot proliferation } \\
\text { (after 3 weeks) }\end{array}$ \\
\hline 1. & MS & $2.37( \pm 0.20)$ & $0.9( \pm 0.25)$ \\
2. & $0.5 \mathrm{mg} / \mathrm{l} \mathrm{NAA}+0.5 \mathrm{mg} / \mathrm{l} \mathrm{BAP}$ & $2.28( \pm 0.79)$ & $7.0( \pm 0.26)$ \\
3. & $0.5 \mathrm{mg} / \mathrm{l} \mathrm{NAA}+1.0 \mathrm{mg} / \mathrm{BAP}$ & $2.002( \pm 0.24)$ & $8.2( \pm 0.39)$ \\
4. & $0.5 \mathrm{mg} / \mathrm{l} \mathrm{NAA}+2.0 \mathrm{mg} / \mathrm{l} \mathrm{BAP}$ & $3.02( \pm 0.85)$ & $8.02( \pm 0.52)$ \\
5. & $0.5 \mathrm{mg} / \mathrm{l} \mathrm{NAA}+3.0 \mathrm{mg} / \mathrm{l} \mathrm{BAP}$ & $2.33( \pm 0.66)$ & $5.02( \pm 0.18)$ \\
6. & $0.5 \mathrm{mg} / \mathrm{IAA}+0.5 \mathrm{mg} / \mathrm{BAP}$ & $2.00( \pm 0.23)$ & $1.2( \pm 0.19)$ \\
7. & $0.5 \mathrm{mg} / \mathrm{lAA}+1.0 \mathrm{mg} / \mathrm{l} \mathrm{BAP}$ & $2.2( \pm 0.16)$ & $5.9( \pm 0.32)$ \\
8. & $0.5 \mathrm{mg} / \mathrm{l} \mathrm{IAA}+2.0 \mathrm{mg} / \mathrm{l} \mathrm{BAP}$ & $1.4( \pm 0.02)$ & $6.3( \pm 0.12)$ \\
9. & $0.5 \mathrm{mg} / \mathrm{lAA}+3.0 \mathrm{mg} / \mathrm{l} \mathrm{BAP}$ & $1.2( \pm 0.12)$ & $3.2( \pm 0.70)$ \\
\hline
\end{tabular}

Each value represents the mean of five replica sets \pm standard error. For induction and proliferation of bulbs $\mathrm{p}<0.05$, hence, the variation is not significant.

After 14 days when shoots were 3 - $5 \mathrm{~cm}$ long in average (Fig 1D) they were transferred to MS containing $0.5 \mathrm{mg} / \mathrm{l} \mathrm{NAA}$ or $0.5 \mathrm{mg} / \mathrm{l} \mathrm{IAA}$ in combination with a series of $\mathrm{Kn}$. From $25 \%$ of the explants grown in a combination of $0.5 \mathrm{mg} / \mathrm{l}$ NAA and $1.0 \mathrm{mg} / \mathrm{l} \mathrm{Kn}$, roots emerged on the 7th day, but for other combinations, the time span was 12 - 13 days in average. Elongation of root was maximum in the medium supplemented with $0.5 \mathrm{mg} / \mathrm{l} \mathrm{NAA}$ and $3 \mathrm{mg} / \mathrm{l} \mathrm{Kn}$. It was measured $7.80 \mathrm{~cm}( \pm 0.31)$ long on the 21st day. Root multiplication was maximum in the medium containing $0.5 \mathrm{mg} / \mathrm{l} \mathrm{NAA}$ and $1 \mathrm{mg} / \mathrm{l} \mathrm{Kn}$ (Table 2).

After one month the shoots with $3-4 \mathrm{~cm}$ root length approximately, were transferred to MS supplemented with $0.5 \mathrm{mg} / \mathrm{l}$ NAA or IAA each in combination with $2 \mathrm{iP}$ of gradual increasing concentration $(0.5,1,2$ and $3 \mathrm{mg} / \mathrm{l} 2 \mathrm{iP})$. Small bulbs of $0.4-0.5 \mathrm{~cm}$ diameter appeared after 28 days when grown in combination of $0.5 \mathrm{mg} / \mathrm{l} \mathrm{NAA}$ and $0.5 \mathrm{mg} / \mathrm{l} 2 \mathrm{iP}$ (Table 3). 
When the medium was supplemented with 2,4-D in different concentrations, callus was formed. Calli were whitish in color, soft and fragile in nature (Fig. E and F). The first undifferentiated mass was formed after 14 days of inoculation. Callusing was highest in MS supplemented with 2 mg/l 2,4-D.

Table 2. Effect of different combinations of plant growth regulators (PGR) on root induction and root proliferation (after 3 weeks).

\begin{tabular}{llll}
\hline $\begin{array}{l}\text { Sl. } \\
\text { No. }\end{array}$ & $\begin{array}{l}\text { PGR } \\
\text { composition }\end{array}$ & $\begin{array}{l}\text { Root } \\
\text { induction }\end{array}$ & $\begin{array}{l}\text { Root } \\
\text { proliferation }\end{array}$ \\
\hline 1. & $0.5 \mathrm{mg} / \mathrm{l} \mathrm{NAA}+0.5 \mathrm{mg} / \mathrm{l} \mathrm{Kn}$ & $3.20( \pm 0.36)$ & $3.70( \pm 0.2)$ \\
2. & $0.5 \mathrm{mg} / \mathrm{l} \mathrm{NAA}+1.0 \mathrm{mg} / \mathrm{l} \mathrm{Kn}$ & $3.34( \pm 0.42)$ & $6.30( \pm 0.40)$ \\
3. & $0.5 \mathrm{mg} / \mathrm{l} \mathrm{NAA}+2.0 \mathrm{mg} / \mathrm{K} \mathrm{Kn}$ & $8.00( \pm 0.69)$ & $17.20( \pm 0.15)$ \\
4. & $0.5 \mathrm{mg} / \mathrm{l} \mathrm{NAA}+3.0 \mathrm{mg} / \mathrm{l} \mathrm{Kn}$ & $6.26( \pm 0.36)$ & $13.50( \pm 0.65)$ \\
5. & $0.5 \mathrm{mg} / \mathrm{IAA}+0.5 \mathrm{mg} / \mathrm{l} \mathrm{Kn}$ & $2.31( \pm 0.12)$ & $3.52( \pm 0.15)$ \\
6. & $0.5 \mathrm{mg} / 1 \mathrm{IAA}+1.0 \mathrm{mg} / 1 \mathrm{Kn}$ & $2.75( \pm 0.25)$ & $4.25( \pm 0.52)$ \\
7. & $0.5 \mathrm{mg} / \mathrm{lAA}+2.0 \mathrm{mg} / \mathrm{l} \mathrm{Kn}$ & $3.32( \pm 0.16)$ & $9.56( \pm 0.36)$ \\
8. & $0.5 \mathrm{mg} / \mathrm{lAA}+3.0 \mathrm{mg} / \mathrm{l} \mathrm{Kn}$ & $2.06( \pm 0.62)$ & $7.22( \pm 0.39$ \\
\hline
\end{tabular}

Each value represents the mean of five replica sets \pm standard error. For induction and proliferation of bulbs $\mathrm{p}<0.05$, hence, the variation is not significant.

Table 3. Effect of different combinations of Plant Growth regulators (PGR) on root induction and root proliferation (after 4 weeks).

\begin{tabular}{|c|c|c|c|}
\hline $\begin{array}{l}\text { Sl. } \\
\text { No. }\end{array}$ & PGR composition & Bulb induction & Bulb proliferation \\
\hline 1. & $0.5 \mathrm{mg} / \mathrm{l} \mathrm{NAA}+0.5 \mathrm{mg} / 12 \mathrm{iP}$ & $1.00( \pm 0.316)$ & $4.4( \pm 0.9)$ \\
\hline 2. & $0.5 \mathrm{mg} / \mathrm{l} \mathrm{NAA}+1.0 \mathrm{mg} / 12 \mathrm{iP}$ & $1.80( \pm 0.374)$ & $7.5( \pm 0.24)$ \\
\hline 3. & $0.5 \mathrm{mg} / \mathrm{l} \mathrm{NAA}+2.0 \mathrm{mg} / 12 \mathrm{iP}$ & $2.00( \pm 0.316)$ & $7.8( \pm 0.82)$ \\
\hline 4. & $0.5 \mathrm{mg} / 1 \mathrm{NAA}+3.0 \mathrm{mg} / 12 \mathrm{iP}$ & $1.00( \pm 0.32)$ & $3.4( \pm .03)$ \\
\hline 5. & $0.5 \mathrm{mg} / 1 \mathrm{IAA}+0.5 \mathrm{mg} / 12 \mathrm{iP}$ & $1.20( \pm 0.36)$ & $3.9( \pm 0.36)$ \\
\hline 6. & $0.5 \mathrm{mg} / \mathrm{l} \mathrm{IAA}+1.0 \mathrm{mg} / 12 \mathrm{iP}$ & $1.50( \pm 0.12)$ & $6.32( \pm 0.52)$ \\
\hline 7. & $0.5 \mathrm{mg} / \mathrm{l} \mathrm{IAA}+2.0 \mathrm{mg} / 12 \mathrm{iP}$ & $1.60( \pm 0.32)$ & $5.01( \pm 0.58)$ \\
\hline 8. & $0.5 \mathrm{mg} / 1 \mathrm{IAA}+3.0 \mathrm{mg} / 12 \mathrm{iP}$ & $0.92( \pm 0.65)$ & $4.23( \pm 0.25)$ \\
\hline
\end{tabular}

Each value represents the mean of five replica sets \pm standard error. For induction and proliferation of bulbs $\mathrm{p}$-value $<0.05$, hence, the variation is not significant.

The explants used for the purpose was bulb scales only. The other explants, namely leaf tip, leaf base, inflorescence stalks get browned within in a week. Onohua et al. (2011) have also reported typical browning of explants and the culture media during in vitro propagation of some Musa species. This is perhaps a consequence of polyphenol secretion in the media by the explant. These 
polyphenols are oxidized by polyphenol oxidases, peroxidases etc. (EI-Shafey et al. 1999). These ultimately lead to formation of toxic quinines (Hu and Wang 1983) which causes tissue death.

Table 4. RAPD analysis with DNA from explant and tissue culture regenerants: List of Primers, their banding patterns with molecular weight and annealing temperature.

\begin{tabular}{|c|c|c|c|c|c|c|}
\hline $\begin{array}{l}\text { Sl. } \\
\text { No. }\end{array}$ & $\begin{array}{l}\text { Primer } \\
\text { sequence }\end{array}$ & $\begin{array}{l}\text { Total no. of } \\
\text { bands in } \\
\text { source plant }\end{array}$ & $\begin{array}{l}\text { Total no. of } \\
\text { bands in } \\
\text { regenerants }\end{array}$ & $\begin{array}{l}\text { Band range } \\
\text { in bp }\end{array}$ & $\begin{array}{l}\mathrm{Tm} \\
{ }^{\circ} \mathrm{C}\end{array}$ & $\begin{array}{l}\text { Figure } \\
\text { reference }\end{array}$ \\
\hline 1. & $5^{\prime}$ TGCCGAGCTG 3' & 10 & 10 & $1517-15.66$ & 38 & $7 \mathrm{~A}$ \\
\hline 2. & $5^{\prime}$ GAAACGGGTG 3' & 12 & 12 & $1483-200$ & 38 & $7 \mathrm{~A}$ \\
\hline 3. & 5'GTGATCGCAG 3' & 15 & 13 & $1503-117.8$ & 39 & 7A \\
\hline 4. & $5^{\prime} \mathrm{CAGCACCCAC} \mathrm{3'}$ & 8 & 8 & $1500.3-120$ & 39 & $7 \mathrm{~A}$ \\
\hline 5. & 5'CAAACGTCGG 3' & 10 & 10 & $1533.7-241.7$ & 38 & $7 \mathrm{~A}$ \\
\hline 6. & 5'AAAGCTGCGG 3' & 8 & 8 & $1517-142.2$ & 38 & $7 \mathrm{~A}$ \\
\hline 7. & 5'TGCGTGCTTG 3' & 9 & 9 & $1450-193.3$ & 38 & $7 \mathrm{~A}$ \\
\hline 8. & 5 'CACACTCCAG 3' & 7 & 4 & $983.3-186.7$ & 38 & $7 \mathrm{~A}$ \\
\hline 9. & 5' CACACICLAG & 9 & 9 & $1433.6-48.99$ & 39 & $7 \mathrm{~A}$ \\
\hline 10. & 5 GGACGACGGI 3 , & 10 & 10 & $1450.3-73.33$ & 39 & $7 \mathrm{~A}$ \\
\hline 11. & 5' GGGTCGCATC 3' & 6 & 7 & $1550.4-97.78$ & 40 & $7 \mathrm{~A}$ \\
\hline 12. & 5'CCACAGCCGA 3' & 11 & 11 & $1567.1-151.1$ & 40 & $7 \mathrm{~A}$ \\
\hline 13. & 5'GTGCGAGAAC 3' & 9 & 9 & $1552-177.1$ & 40 & $7 \mathrm{~B}$ \\
\hline 14. & 5'TGCGGGTTCC 3' & 15 & 11 & $1481-79.17$ & 38 & $7 \mathrm{~B}$ \\
\hline 15. & 5' CTTCGGTGTG 3' & 13 & 13 & $1446.3-312.5$ & 38 & $7 \mathrm{~B}$ \\
\hline 16. & 5' GTTCGCTCCC 3' & 12 & 12 & $1481-212.5$ & 38 & $7 \mathrm{~B}$ \\
\hline 17. & 5'GAGCTGGTCC 3' & 12 & 12 & $1534.6-210$ & 39 & $7 \mathrm{~B}$ \\
\hline 18. & $5^{\prime}$ AGGCCGGTCA 3' & 11 & 9 & $967.5-189.6$ & 40 & $7 \mathrm{~B}$ \\
\hline 19. & $5^{\prime}$ AAGTGCCCTG 3' & 10 & 10 & $1146.6-193.8$ & 38 & $7 \mathrm{~B}$ \\
\hline 20. & 5'TCATCCGAGG 3' & 6 & 12 & $1464-77.08$ & 39 & $7 \mathrm{~B}$ \\
\hline 21. & $5^{\prime}$ ACCAGGTCAC 3' & 8 & 7 & $1522.2-280$ & 40 & $7 \mathrm{~B}$ \\
\hline
\end{tabular}

Within seven days of media inoculation, the first shoot was initiated on MS (Fig. 1B). Supplementation of BAP with a low concentration of NAA also helped initiation. When NAA was replaced by IAA, the rate of shoot induction was little slower. These supplementations also resulted in shoot elongation as well as multiplication. Jafari et al. (2011) have reported similar findings while micropropagating Musa. According to them a higher concentration of BAP is required for the purpose of shooting. Theoretically, BAP reduces apical dominance thus inducing the 

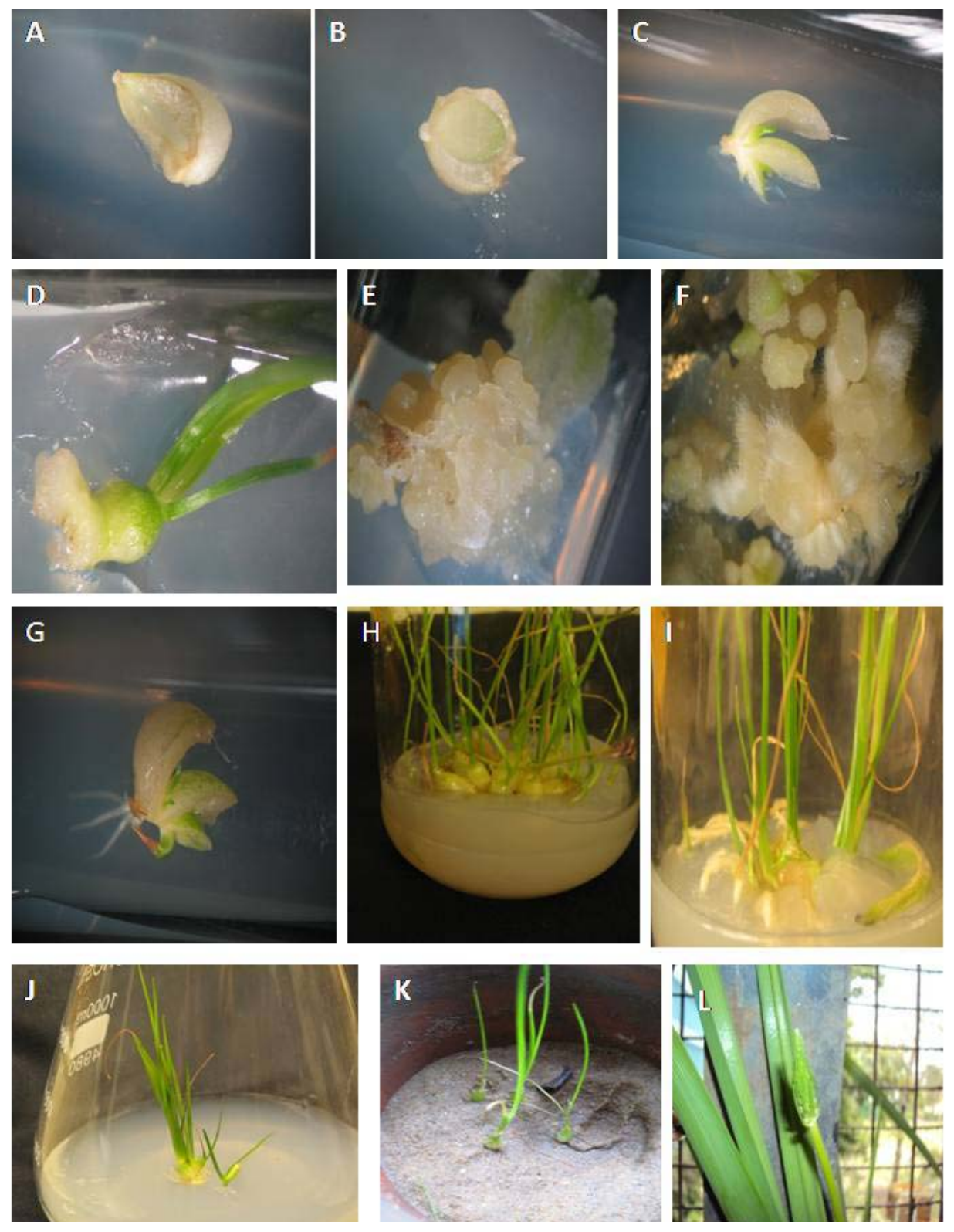

Fig. 1. Micropropagation of Ornithogalum virens. A. 0-day-plant on basal medium, B and C. Shoot initiation in medium containing $0.5 \mathrm{mg} / \mathrm{l} \mathrm{NAA}$ and $2 \mathrm{mg} / \mathrm{l} \mathrm{BAP}, \mathrm{D}$. 14-daysold callus (2 mg/l 2,4-D), E. 30 days old callus(2 mg/l 2,4-D), F. 45-days-old callus (2 $\mathrm{mg} / \mathrm{l}$ 2,4-D), G. root induction $(0.5 \mathrm{mg} / \mathrm{l} \mathrm{NAA}$ and $2 \mathrm{mg} / \mathrm{l} \mathrm{Kn}), \mathrm{H}$. tissue culture regenerated bulb $(0.5 \mathrm{mg} / \mathrm{l} \mathrm{NAA}, 2 \mathrm{mg} / \mathrm{l}$ 2iP; I and J. Full grown plant, K. Plants on hardening, L. Six-Months-old plant with inflorescence. 
formation of either axillary or adventitious shoots (Jafari et al. 2011). Seyyedyousefi et al. 2013, found similar result in Alstroemeria. While working with Allium sativum, Roksana et al. (2002) also reported similar results. Culture medium supplemented with $1.5 \mathrm{mg} / \mathrm{l} \mathrm{BAP}$ and $0.5 \mathrm{mg} / \mathrm{l} \mathrm{NAA}$ elicit shoot initiation response in $90 \%$ of the explants. The root was initiated in the media supplemented with low NAA or IAA in combination with Kn (Fig 1G). Normally Kn inhibits root initiation. According to Wang et al. (2002) it stimulates ethylene biosynthesis under some conditions thus preventing rooting. In present experiment, opposite result is obtained. Kn supplementation in media resulted in root induction. Sharma (1993) reported induction of root by $\mathrm{Kn}$ in Commiphora wighti and C. agallocha. Ahuja (2000) reported similar results in Tinospora cordifolia. Deshwal and Trivedi (2011) have also reported similar results i.e., Kn induces tuberous root formation in Chlorophytum borivilianum.

Normally in tissue culture bulbs are induced by stress. The stresses of different kinds such as higher sucrose concentration, water stress induced by mannitol or polyethylene glycol in the media or even temperature shock result in bulblet formation. In our experiment bulbs were induced in the medium supplemented with NAA and 2iP. From a single bulb scale, 15 - 37 bulblets have been produced within 16 weeks of culture (Fig. 1H). Uranbay (2010) reported similar results in bulb induction in Muscari aucheri in the medium supplemented with 2iP. Keller (1993) reported bulb formation in onion and leek when grown in the medium supplemented with $150 \mathrm{~g} / \mathrm{l}$ sucrose instead of normal 3\%. In our experiments bulb induction took place in MS fortified with $3 \%$ sucrose and supplemented with $0.5 \mathrm{mg} / \mathrm{l} \mathrm{NAA}$ and $0.5 \mathrm{mg} / 1$ 2iP (Fig. $1 \mathrm{H}$ ).

The karyotype from the root of the source plant of $O$. virens (Fig. 2) shows either $(2 n=6$ or $2 n=12$ chromosomes. The frequency of $2 n=6$ is higher (70 $75 \%$ ) while remaining $25-30 \%$ show $2 n=12$ chromosomes. From the i-values of the chromosomes, it seems all the chromosomes are acrocentric (St) for both $2 n=6$ and 12. The chromosome lengths ranged from 7.684 to $9.84 \mu \mathrm{m}$ for $2 n=6$ chromosomes and 6.7082 to $8.933 \mu \mathrm{m}$. The pair of longest chromosomes of the $2 \mathrm{n}$ $=6$ plate has a hook like structure on their short arm. This hook is not prominent among $2 \mathrm{n}=12$ chromosomes (Fig. 3A).

Cytology of calli revealed a high frequency of numerical abnormality of chromosomes. The lowest number recorded was $2 n=3$ (Fig. 6B) and the highest was $2 n=76$ (Fig. 6A) along with some normal $2 n=6$ chromosomes (Fig. 6C).

Cytology of in vitro grown roots reveals only $2 n=6$ chromosomes (Fig. 5A), the frequency of $2 n=12$ being almost absent. The morphology of chromosomes is similar to that found in the source plants. 


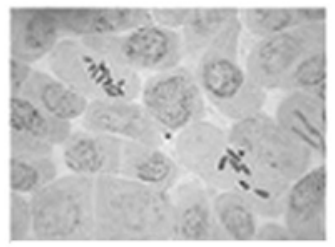

2

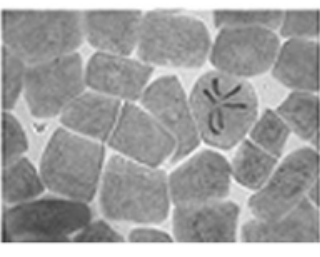

3A

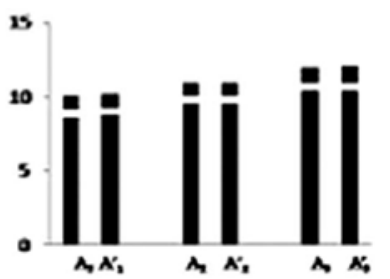

3B
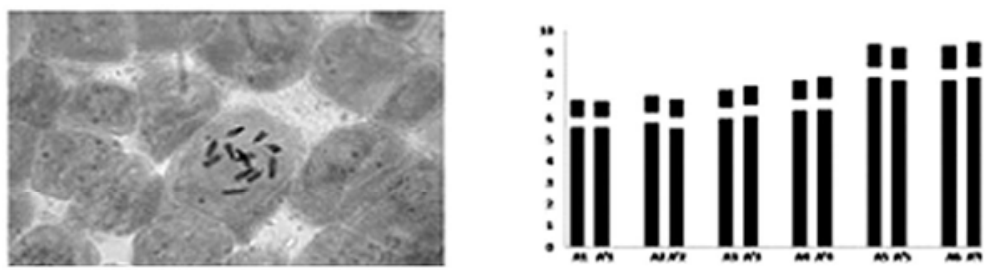

4A
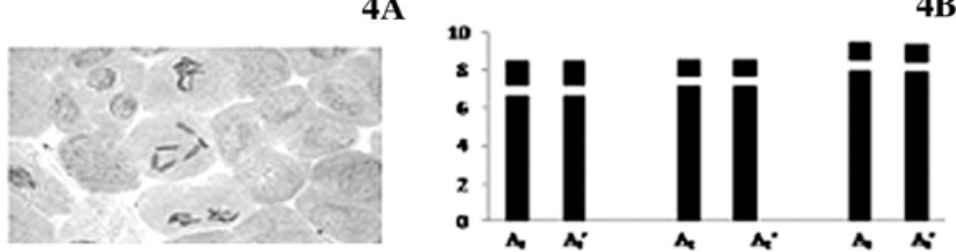

$5 A$

5B

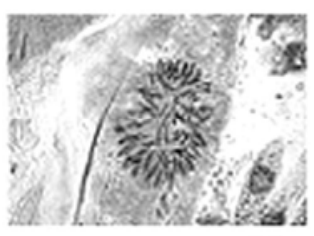

6A

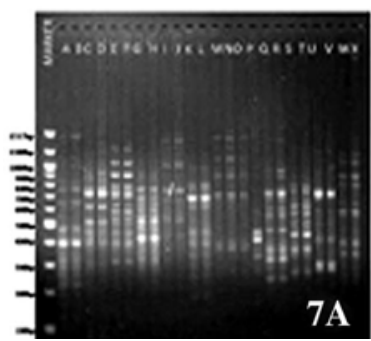

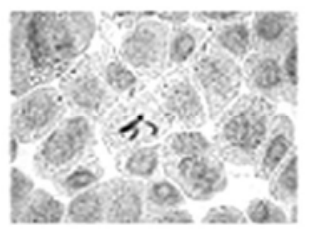

6B

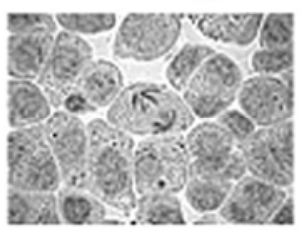

$6 \mathrm{C}$

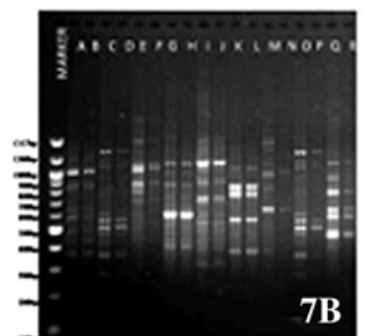

Fig. 2. Mitotic metaphase plate of $O$. virens showing polysomaty, $2 n=6$ and $2 n=12$. Fig. $3 A$, B. Metaphase plate of source plant showing $2 n=6$ chromosomes and its idiogram; Fig. 4A,B. Metaphase plate of source plant showing $2 n=12$ chromosomes and its idiogram. Fig. 5A, B. Metaphase plates of roots of regenerated plant showing $2 n=6$ chromosomes and its idiogram; Fig. 6A,B,C. Callus cytology of O.virens showing hyperploidy $(2 n=72)$, hypoploidy $(2 n=3)$ and normal $2 n=6$ chromosome, respectively. Fig. 7A, B. RAPD analysis of source plants and tissue culture regenerants: The lane marked as marker is a 100 bp ladder in both ; $\mathrm{A}, \mathrm{C}, \mathrm{E}, \mathrm{G}, \mathrm{I}, \mathrm{K}, \mathrm{M}, \mathrm{O}, \mathrm{Q}, \mathrm{S}, \mathrm{U}, \mathrm{W}$ of figure $7 \mathrm{~A}$ and $\mathrm{A}, \mathrm{C}, \mathrm{E}, \mathrm{G}, \mathrm{I}, \mathrm{K}, \mathrm{M}, \mathrm{O}, \mathrm{Q}$ of $7 \mathrm{~B}$ are of source plant DNA and $B, D, F, H, J, L, N, P, R, T, V, X$ of figure $7 A$ and $B, D, F, H, J, L, N, P, R$ of $7 B$ are of DNA from tissue culture regenerants. Primer details are given in Table 4. 
Ornithogalum is reported to show a high degree of cytological differentiation. In India the species O. virens, O. thyrsoides and O. umbellatum are found to occur, the former being a tropical species whereas the latter two remain confined in the temperate region. Of these, the last two species have been reported to differ significantly in their karyotype. Such variation has been well studied in several species outside India. Kushnir and Galil (1977) grouped different species of Ornithogalum into three different pairs based on karyological differences correlated with dissimilarities in external morphology. Couderc et al. (1985) found the chromosome numbers of $O$. divergens vary within different populations, different individuals of the same population or between different organs in the same individual. It is to be mentioned here that O. divergens is a synonym to O. umbellatum. Rammsdonk et al. (1987) described O. umbellatum representing a polyploid-complex with chromosome number ranging from $2 \mathrm{n}=$ 18 to $2 \mathrm{n}=54$ (thus having basic chromosome number $\mathrm{x}=9$ ). Moretand and Gallard (1991) identified this polyploidy complex to three morphs $(2 n=2 x=18)$, triploid morph $(2 \mathrm{n}=3 \mathrm{x}=27)$ and ploidy morph above $3 \mathrm{x}(2 \mathrm{n}=4 \mathrm{x}=36 ; 2 \mathrm{n}=5 \mathrm{x}=$ $45 ; 2 n=6 x=54)$. Karyotype study of a haploid set of this species reveals one SAT chromosome of the medium size, three large and three small chromosomes each with a submedian centromere (Czapik 1968). Triploidy progenies in this species show a wide range of chromosome variation from $2 n=18,30,32$, 36. Griesbach et al. (1993) studied the karyotype of $O$. thyrsoides which contains 5 pairs of long and one pair of short chromosomes having somatic chromosome number $2 n=12$. However, in our lab we have found $O$. thyrsoides to possess a bimodal karyotype which varies in having 8 long and 4 short chromosomes or in some plants 10 long and 2 short chromosomes. O. virens contains almost symmetrical karyotype having $2 \mathrm{n}=6$ with acrocentric chromosomes. However, some cells of the same plant was found to possess $2 \mathrm{n}=12$ chromosomes indicating polysomaty. From the morphology of the chromosomes, it seems that $2 n=12$ may be a whole genome duplication of $2 \mathrm{n}=6$ chromosomes.

The basic chromosome number of Ornithogalum in sub-Sahara members was found to be $x=6$ but the Eurasian members have the base number of $x=7,8,16$ (Goldblatt and Manning 2011). O. umbellatum polyploidy series show a base number $\mathrm{x}=9$. It is evident that as Ornithogalum is chiefly propagated vegetatively, it might be one of the reasons for such chromosomal variation. Keeping in mind about the different basic numbers, the occurrence of smaller number of aneuploids in this genus is possibly due to the elimination of additional chromosomes (Czapik 1968).

The cytological study of the callus shows a great variation in chromosome number that ranges from 3 to 72 . Hence, aneuploidy, as well as polyploidy 
prevails in callus condition. Significantly, such variations in the ploidy level in this species are not found from the roots grown in vitro. Perhaps it is due to selection pressure during organogenesis, whereby cellular totipotency has selectively played the role in formation of organ. The cells which are highly polyploid lose their potential to differentiate (Jha and Sen 1987). The presence of polysomaty in the roots of the source plant but its absence in the tissue culture derived regenerants is quite unusual. This aspect needs further investigation. The RAPD analysis of the source plant and its regenerants shows that the regenerants and source plant give almost equal number of bands when annealed with similar primer. Five primer sets produce a greater number of bands in which the DNA of the source plant is used as a template (Table 4). Moreover, the intensity of the bands of the source plant was observed to be more than that of the regenerants. This perhaps is in agreement with the fact that in the source plant the somatic chromosome number is $2 n=6$ and 12 , whereas in regenerants it is always $2 n=6$.

\section{Acknowledgement}

This work has been financially supported by University Grants Commission [F. No. 42-965/2013(SR)]. The authors also like to thank their colleagues from Department of Biological Sciences, Presidency University, Kolkata and Department of Botany RKMVC College, Rahara, for their constant assistance and co-operation.

\section{References}

Ahuja K (2000) Studies on phenotypic variation. clonal propagation and phytochemistry of Tinosporacordifolia (Willd.) Ex Hoof.f. et. Thomas. In: Ph.D. Thesis, Univ. Rajasthan, Jaipur.

Couderc H, Gorenflot R, Moretm J and Siami A (1985) Caracteristiqueset consequences de la variation Chromosomique Chez Ornithogalum divergens Boreau. Bull. Soc. Bot. Fr., Actual. Bot. 132(2): 63-71.

Czapik R (1968) Chromosome numbers of Ornithogalumum bellatum L. from three localities in England. Watsonia. 6(6): 345-349.

Deshwal RK and Trivedi PC (2011) Effect of Kn on enhancement of tuberous root production of Chlorophytumborivilianum. International Journal of Innovations in Biological and Chemical Sciences 1: 28-31.

Ebrahimzadeh MA, Nabavi SM, Nabavi SF and Eslami B (2010) Antioxidant activity of the bulb and aerial parts of Ornithogalum sintenisii L. (Liliaceae) at flowering stage. Trop. J. Pharm. Res. 9(2): 141-148. 
El-Shafey YH, Anesiem MR, Habib MW and Abdel-Sattar (1999) Browning phenomenon: A serious problem in date palm tissue culture: Proc. Int. Conf. Date Palm. [Assiut.Univ. Egypt.]. 53-74.

Goldblatt and Manning (2011) Systematics of the southern African genus Ixia (Iridaceae): 3. Sections Hyalis and Morphixia. Bothalia 41: 83-134

Griesbach RJ, Meyer F and Koopowitz H (1993) Creation of new flower colors in Ornithogalum via interspecific hybridization. J. Amer. Soc. Hort. Sci. 118(2): 409-414.

Hu, CY and Wang PJ (1983) Meristem, shoot tip and bud cultures. In: Handbook of Plant cell culture, Evans, D.A, W. R. Sharp, P.V. Ammirato and Y. Yamada (Eds) MacMillan Publishing Company, New York. pp. 177-227.

Jafari N, Othman RY and Khalid N (2011) Effect of benzylaminopurine (BAP) pulsing on in vitro shoot multiplication of Musa acuminata (banana) cv. Berangan. African Journal of Biotechnology 10(13): 2446-2450,

Jha S and Sen S (1987) Nuclear changes and organogenesis during callus culture of Urginea indica Kunth., Indian squill. Cytologia 52: 433-438.

Karaguzel O, Kaya A, Biner B and Aydinsakir K (2012) In vitro propagation of native Ornithogalum species in west Mediterrenean region of Turkey. African J. Agril. Res. 7(17): 2669-2673.

Keller ERJ (1993) Sucrose, cytokinin and ethylene influence formation of in vitro bulblets in onion and leek. Genetic Resources and Crop Evolution. 40(2): 113120.

Komissarenko NF (1971) Ornithogalin - A cardenolide glycoside from Ornithogalum magnum. Khimiya Prirodnykh Soedinenii 7(1): 33-35.

Komissarenko NF (1972). Cardenolides of the seeds of Ornithogalum magnum. Khimiya Prirodnykh Soedinenii. 8(3): 395-396.

Kuroda M, Mimaki Y, Yokosuka A, Hasegawa F and Sashida Y (2002) Cholestane glycosides from the bulbs of Ornithogalum thyrsoides and their cytotoxic activity against HL-60 leukemia cells. Nat. Prod. 65(10): 1417-1423.

Kushnir U and Galil J (1977) Cytology and Distribution of Ornithogalum in Israel I. Section Heliocharmos Bak. Israel J. Bot. 26: 63-82.

Mbaka J (2003) Integrated pest management (IPM) options for management of soft rot of arabicum. In: NHRC Annual Report.

Moret J and Galland N (1991) Characterization des Taxon du Genre, Ornithogalum, SousGener Heliocharmos (Hyacinthaceae), en Afrique du Nordeten France: Analyse Morpholoiqueet Biogeographique. Can. J. Bot. 69: 1787-1794.

Muthoka NM (2008) Smallholder summer flower production in Kenya: A myth or a prospect? Acta. Hort. 766: 219-224.

Nayak S and Naik PK (2005) Different modes of plant regeneration and factors affecting in vitro bulblet production in Ornithogalum virens. Science Asia. 31: 409-414.

Obermeyer AA (1978). Ornithogalum: a revision of the southern African species. Bothalia. 12(3): 323-376.

Onuoha IC, Eze CJ and Unamba CI (2011) In vitro Prevention of browning in plantain culture. On Line J. Biol. Sci. 11: 13-17. 
Rammsdonk L, Van DW and Heringa J (1987) Biosystematic Studies on the umbellatumangustifolium complex in the genus Ornithogalum (Liliaceae) morphological analysis. Nord. J. Bot. 7(6): 631-637.

Roksana R, Alam MF, Islam R and Hossain MM (2002) In vitro bulblet formation from shoot apex in Garlic (Allium sativumL.). Plant Tissue Culture 12(1): 11-17.

Seyyedyousefi SR, Kaviani B, Dehkaei NP and Salehzadeh A (2013) Callus induction in Alstroemeria using NAA and BAP. Euro. J. Exp. Bio. 3(5): 137-140.

Sharma AK and Sharma A (1980) In: Chromosome techniques. Theory and practice.3rd ed. Butterworths, London.

Sharma R (1993) Reproductive biology of Guggal plant. Commiphora wightii (Arnott.) Bhandari and Commiphoraa galocha, In: Ph.D. Thesis, University of Rajasthan, Jaipur.

Smith CA (1966) Common names of South African Plants, Memories of Botanical Survey of South Africa, No. 35, Government Printer, Pretoria.

Tang Y, Yu B, Hu J, Wu T and Hui H (2002) Three new homoisoflavanone glycosides from the bulbs of Ornithogalum caudatum. J. Nat. Prod. 65(2): 218-220.

Uranbay S (2010) Stimulating effect of different basal media and cytokinine types on regeneration of endemic and endangered Muscariaucheri. Arch. Biol. Sci. 62(3): 663-667.

Wang KL, Li H and Ecker JR (2002) Ethylene biosynthesis and signaling networks. Plant Cell. 14: 131-151.

Zhou Y, Garcia-Prieto C, Carney DA, Xu RH, Pelicano H, Kang Y, Yu W, Lou C, Kondo S, Liu J, Harris DM,Estrov Z,Keating MJ,Jin Z and Huang P (2005) OSW-1: A natural compound with potent anticancer activity and a novel mechanism of action. J. Nat. Cancer Inst. 97(23): 1781-1785. 